\title{
Population structure, condition index and age structure of the Mediterranean carpet shell clams Donax semistriatus and Donax trunculus (Mollusca: Bivalvia) in Idku, Egypt
}

\author{
Rabab M. I. Alkaradawe'; Samya H. Mohammad²*; Saad Z. Mohamed $^{3}$ and \\ Zakaria S. Morsy ${ }^{1 .}$ \\ 1- Department of Biology, Faculty of Education, Suez Canal University \\ 2- Department of Zoology, Faculty of Science, Port Said University \\ 3- Department of Marian Biology, Faculty of Science, Suez Canal University
}

\section{ABSTRACT}

This study investigates the population structure and shell morphometric relationships for the most common bivalve species in Egypt; Donax semistriatus and Donax trunculus. The clams were monthly collected from November 2008 to May 2010 from two sites on the Mediterranean coast, Idku city, Behira governorate, North Egypt. The most dominate size of the calm D. semistriatus is the individuals with class intervals of 12.1-16 mm. For $D$. trunculus, animals with size class intervals of 18.1-22 $\mathrm{mm}$ and 14.1-18 $\mathrm{mm}$ dominated site 1 and site 2 respectively. The population of $D$. semistriatus showed two periods of recruitments each year whilest that of $D$. trunculus recorded one period only. The results also showed apparent general tendency toward negative allometry in most relationship between shell length and each of shell measurements and body weigh parameters. Positive allometric growth exhibited in gonad weight / shell length and dry weight/shell length relationships. The growth rate at site 2 slightly higher than that at site 1 for the two clams. Gonad indices of both species were more or less coincided with the reproductive activity. In addition, digestive gland and condition indices were also discussed in the present study. Age determination using Bhattacharya's method revealed that D. semistriatus and $D$. trunculus recorded three age groups at both sites. Several ecological explanations were formulated for the two bivalve species.

Keywords: Donax, morphometric relationships, allometric growth, Idku, Egypt.

\section{INTRODUCTION}

Exposed sandy beaches are one of the most dynamic and rich environments, where they being constantly moved by waves, winds, and tides. Egyptian sandy beaches are commonly dominated by bivalves of the family Donacidae. Donacidae can acquire an important role in solving the problem of shortage and high price of animal protein in Egypt. In addition, bivalve fisheries play an important role in socialeconomic context, mainly due to number of fishermen involved in this activity.

The most common and edible bivalves Donax semistriatus and Donax trunculus have been reported on the Egyptian Mediterranean coasts such as Alexandria (Frihy et al., 2004), Port said city (El-refaey, 2006 and Ali et al., 2009), Damietta and El-Jamil (El Nemr et al., 2012).

The biology and population dynamics of Donax trunculus were also studied by Manca Zeichen et al. (2002) along the Italian Southern Adriatic coast. Manatrinon et al. (2011) studied the morphological variation among five populations of Donax spp. in Prachaupkhirikhan, Thailand. 
El-Ghalban (2010) stated that the population structure was unimodal with the dominance of 10.1-20 mm class sizes. She added that most relationships between length and other shell dimensions or weights showed negative allometric growth.

Positive allometry and isometry was recorded in Donax semistriatus for $\mathrm{H} / \mathrm{L}$ and W/L relationships respectively (Gaspar et al. 2002).

The growth of both natural and artificially seeded populations of Anadara granosa (L.) was studied by Broom (1982), who declared that density and exposure (height on the shore) are the major factors influencing growth rate of the natural populations.

Mohammad (2008) showed that the vertical zonation has a great effect on population structure and biometric relationships of the intertidal snail Cerithium scabridum. Mohammad (2002) studied the gonad and digestive indices of the bivalve Cerastoderma glaucum and reported that they are inversely correlated with each other.

Also, Mane and R- Nagabhushanam (1988) mentioned that the gonad index of Meretrix meretrix which showed maximum value before spawning season.

Orban et al. (2006) investigated the condition index of Chamelea gallina clams to show the nutritional and commercial importance for this bivalve. Also condition index of the surf clam Donax serra was studied by Laudien et al. (2001) as indication to the reproductive cycle of this species, however Herrmann et al. (2009) mentioned that the condition index was not useful in describing the annual reproductive cycle of Mesodesma mactroides.

Several studies on the growth of Donax have been conducted. Most of these studies based on analysis of the monthly progression of the mean size of each cohort identified in size frequency distributions and showed that there is a seasonal pattern to shell growth. Laudien (2002) applied a von Bertalanffy growth function on Donax serra inhabiting beaches of the Benguela upwelling system. Manca Zeichen et al. (2002) recorded the growth parameters of $D$. trunculus from Italy. El-Ghalban (2010) recorded asymptotic length for Egyptian $D$. trunculus. She also detected three age groups for D. trunculus inhabiting the Mediterranean sea of Port Said city (Egypt).

Ansell et al. (1980) identified five age groups for European Donax vittatus. Neuberger-Cywiak et al. (1990) found that Mediterranean D. trunculus shows a life span of about 3 years.

Ramón et al. (1995) declared that ring formation in Donax trunculus occur in clams larger than $25 \mathrm{~mm}$. El-refaey (2006) studied the age of $D$. semistriatus and $D$. trunculus inhabiting the Mediterranean sea water at the western area of Gamasa city and the eastern area of Port Said city (Egypt) respectively.

\section{MATERIAL AND METHODS}

\section{Study area}

Idku city located on the Mediterranean coast in Behira governorate, North Egypt (Latitude: $31.31^{\circ} \mathrm{N}$, Longitude: $30.3^{\circ} \mathrm{E}$ ). The altitude of Idku was $6 \mathrm{~m}$ (Plate 1. a \& b). The samples were collected from two regions that exposed to different pollutions in order to see the differences in population structure, growth and maturity stages of the clams between the two sites. Site 1 located at waterway that discharges waste water (result from irrigation) into the sea. The other selected region (site 2) is located near other sources of pollution (harbor and Petroleum Company). 


\section{Sampling}

A total of 2397 specimens of Donax sp. of different size were examined: 2158 specimens of $D$. semistriatus and 239 specimens of $D$. trunculus. The samples were monthly collected from November 2008 to May 2010. The samples were collected at approximately $1 \mathrm{~m}$ in depth using simple harvesting tool (hand dredge).

\section{Population structure and biometric studies}

The morphometric analysis was made by measurement of the three shell axes;

1- Shell length: maximum distance on the anterior-posterior axis

2- Shell height: maximum distance on the dorsal-ventral axis

3- Shell width: maximum distance on the lateral axis (Plate 1 c \& d)

All the measurements were taken to the nearest $0.01 \mathrm{~mm}$ with a manual Vernier calliper.

Each specimen was weighed using electric balance with a precision of $0.001 \mathrm{~g}$ (total weight). The soft parts were removed, dried on paper towel and weighted (soft weight), then dried at $85 \circ \mathrm{C}$ for 48 hours and weighted again (dry weight). Empty shell was also weighted (dry weight)

\section{Statistical analysis}

Morphometric relationships between parameters was estimated by using the following allometric equation;

$\log Y=\log a+b \log X$

where $Y=$ dependent variable; $X=$ independent variable; $a$ =intercept (initial growth coefficient); $b=$ slope (relative growth rate of variables). The parameters $a$ and $b$ of the morphometric relationships were estimated by linear regression analysis, and the association degree between variables was calculated by the determination coefficient $\left(R^{2}\right)$. When the two variables having the same units of measurements, they are included in the isometric range $(b=1)$ or allometric ranges (negative allometry: $b<1$ or positive allometry: $b>1)$. If the dimensions of $X(\mathrm{~mm})$ differ from that of $Y(\mathrm{~g})$, a different criteria is applied; the isometric range $(b=3)$ or allometric ranges (negative allometry: $b<3$ or positive allometry: $b>3$ ). Additionally, the $95 \%$ confidence limit of

Condition Index (CI);

$b$ was also estimated.

Condition Index was calculated as follows:

$$
\mathrm{CI}=\frac{\mathrm{MDW}}{\mathrm{SDW}} \quad \mathrm{X} 1000 \quad \text { (Orban et al., 2006) }
$$

Where MDW is meat dry weight (g) and SDW is shell dry weight (g).

\section{Age determination} FISAT_II.

Age was estimated by using Bhattacharya's method from the program of

\section{RESULTS}

\section{Population structure \\ Donax semisteriatus}

Size frequency distribution of $D$. semisteriatus at both sites is pointed in (Fig. 1 A). Their sizes ranged from $4.5-24 \mathrm{~mm}$ in site1 and from $6.7-23.4 \mathrm{~mm}$ in site 2. The large and small clam individuals were found with low frequency at both sites. Clams within class interval of 12.1-16 mm dominated the population. Their frequency percentages were 49.76 and 46.3 for site 1 and site 2 respectively. 


\section{Donax trunculus}

The size of $D$. trunculus ranged between 12.4-31.3 mm for site1, and between 11.7-31.3 mm for site 2 (Fig.1 B). Clams within class intervals of 18.1-22 mm and 14.1-18 mm dominated the population with frequency percentage of 38.02 and 40.68 for site 1 and site 2 respectively.

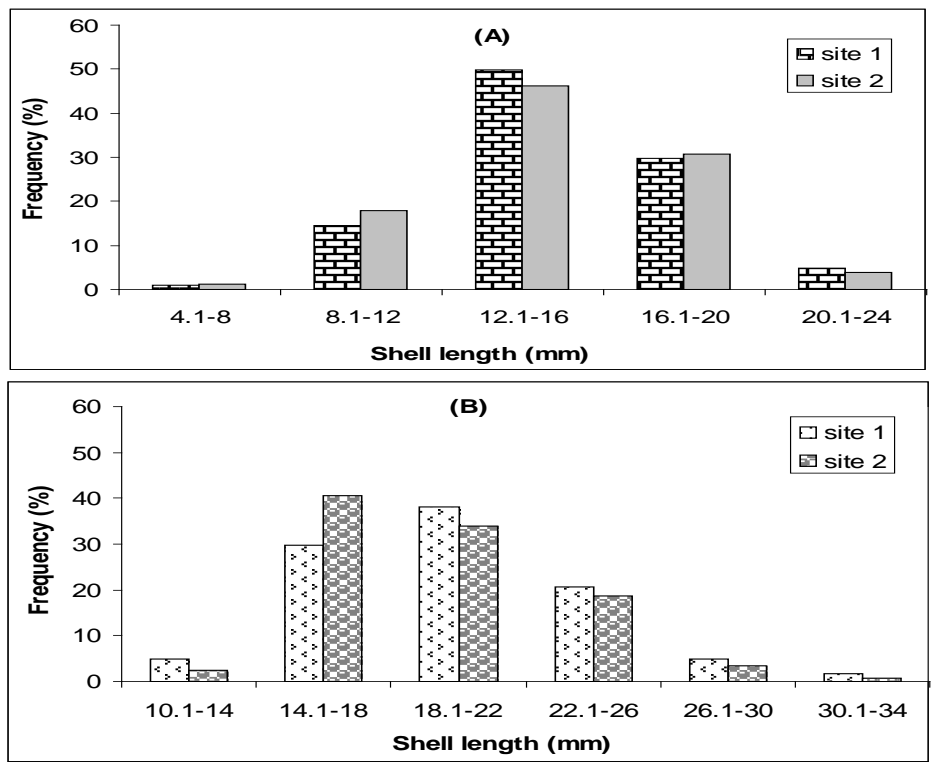

Fig. 1: Frequency distribution of Donax semistriatus (A) and Donax trunculus (B) at both studied sites.

\section{Length frequency distribution Donax semisteriatus}

Frequency distribution in the different months at site 1 was graphed in Fig. (2). The smallest clams appeared in June, increased in July 2009 and found with small percentage in November 2009, while the largest one dominated the population in June 2009. Clams within class interval 12.1-16 mm shell length dominated the population in most months followed by that within class interval $16.1-20 \mathrm{~mm}$. Those within class interval 8.1-12 mm dominated the population together with that of 12.1-16 mm in July 2009.

In site 2, the dominate size was within the class interval 12.1-16 mm shell length followed by the size class $16.1-20 \mathrm{~mm}$. The smallest individuals appeared in December 2008, Jun, July and November 2009. The large one (20.1-24 mm shell length) first appeared in March 2009 and continued to the last period with the exception in some months (Fig. 3).

\section{Donax trunculus}

Fig. (4) showed frequency distribution at site 1 . The smallest size of the clams (10.1-14 mm shell length) is found in equal proportion together with that of 14.1-18 and 18.1-22 $\mathrm{mm}$ in October 2009. The largest one recorded only in Jun 2009. The dominate sizes at site 1 were within class interval 14.1-18, 18.1-22 and 22.1-26 mm.

At site 2, clams within class interval 10.1-14 mm shell length appeared in November 2009 and extended till January 2010. The largest clams only appeared in September 2009. Clams within class interval 14.1-18 mm dominated the population from December 2008 till February 2009 then from September 2009 to January 2010. However, that of class interval 26.1-30 mm observed only in March and April 2010 (Fig. 5). 


\section{Biometric studies}

This study was carried out on different body parameters for shell height (SH), shell width (SW), total weight (TW), wet weight (WW), shell weight (SW), flesh dry weight (DW), intestine weight (IW), and gonad weight (GW) against shell length (L) as independent parameters (Tables $1 \& 2$ ).
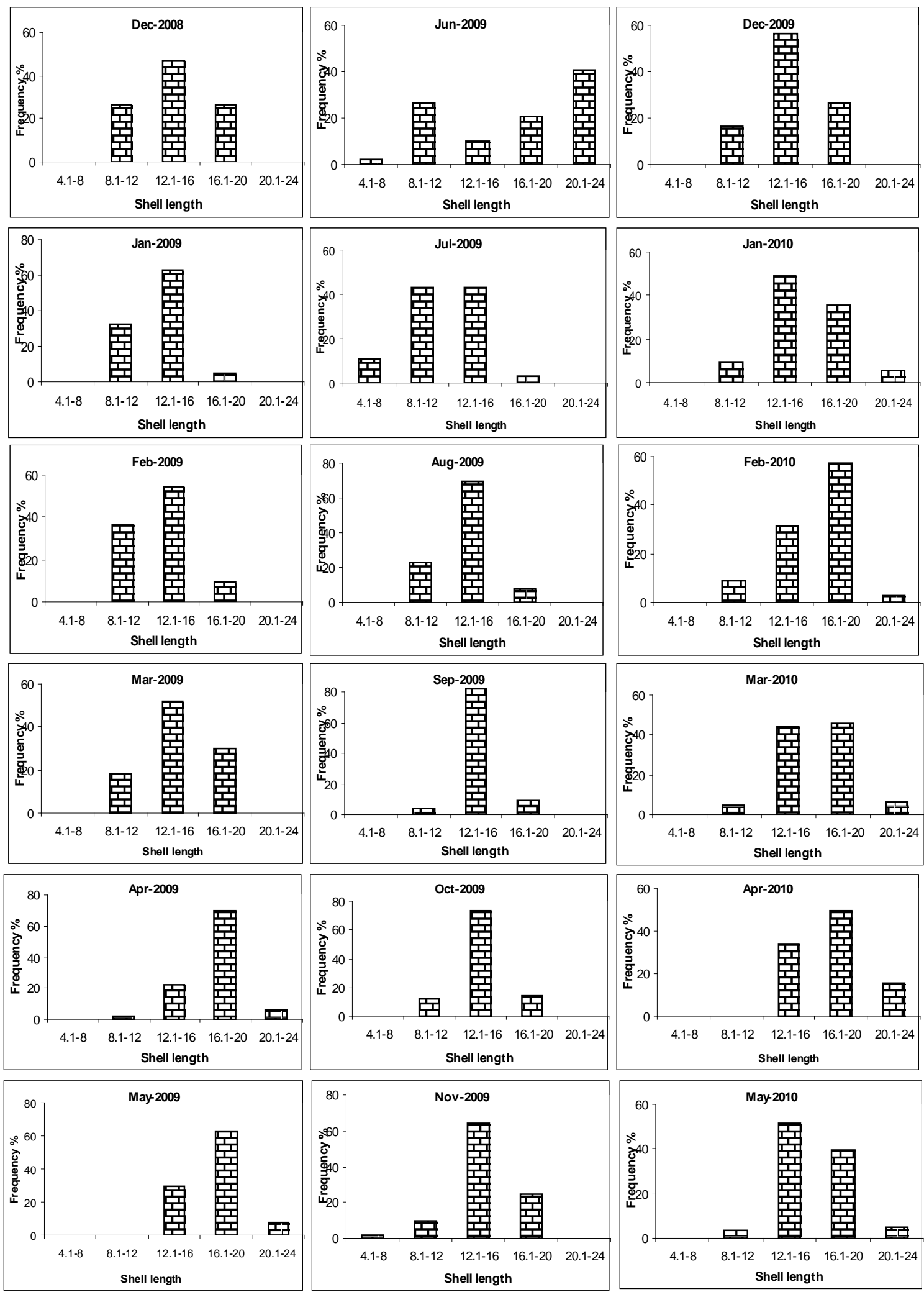

Fig. 2: Monthly length-frequency distribution of Donax semistriatus in site 1 
Rabab M. I. Alkaradawe et al.

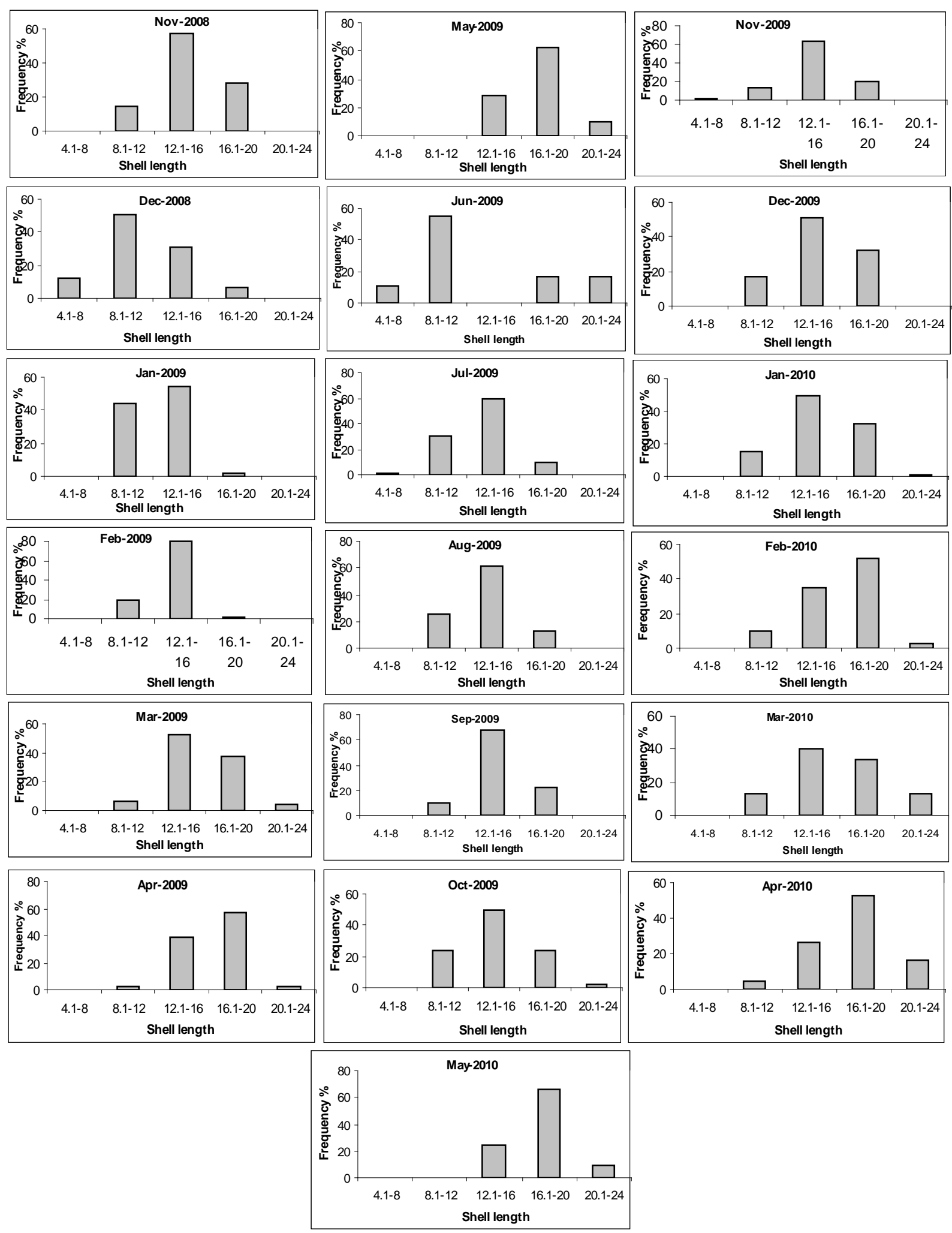

Fig. 3: Monthly length-frequency distribution of Donax semistriatus in site 2 

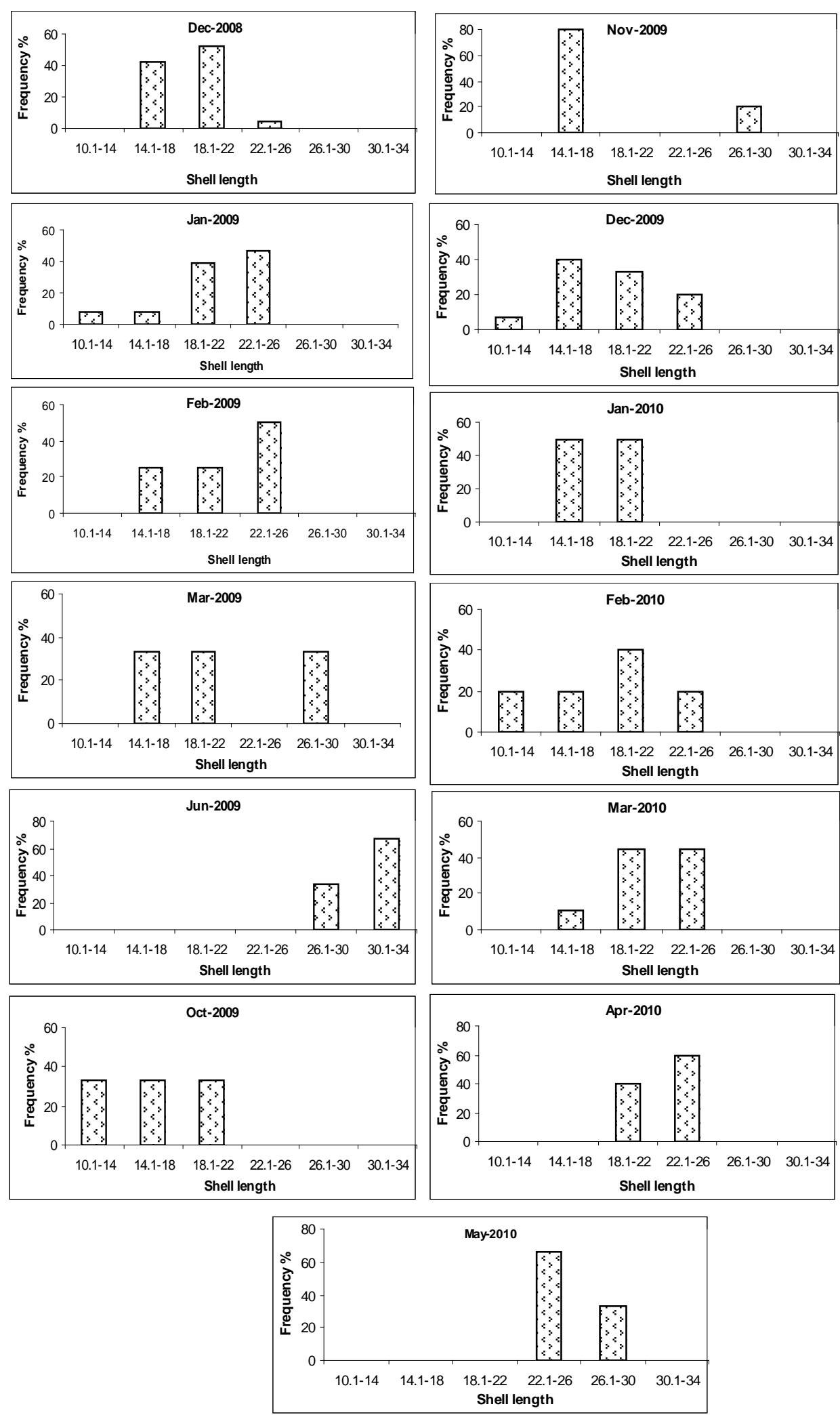

Fig. 4: Monthly length-frequency distribution of Donax trunculus in site 1 


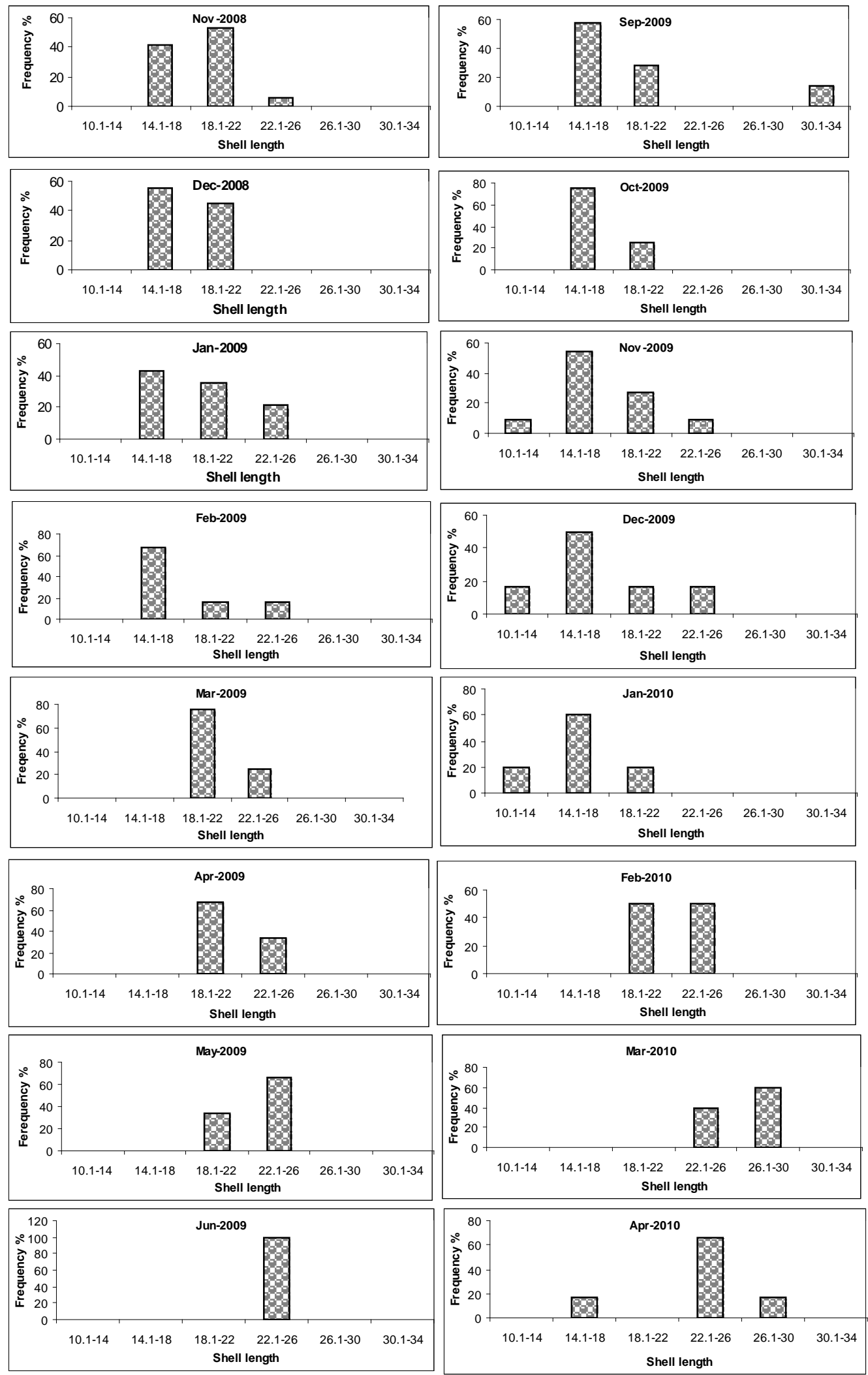

Fig. 5: Monthly length-frequency distribution of Donax trunculus in site 2 
Table 1: Values of regression equations describing the relative growth between shell length (mm) and each of shell measurements and weights of Donax semistriatus at both studied sites.

\begin{tabular}{|c|c|c|c|c|c|c|c|c|c|c|c|c|}
\hline Site & $\begin{array}{l}\text { Measurements } \\
\text { and weights }\end{array}$ & No. & a & SE & $\begin{array}{c}\text { Lower } \\
95 \% \\
\text { C.L. for a } \\
\end{array}$ & $\begin{array}{c}\text { Upper } \\
95 \% \\
\text { C.L. for a } \\
\end{array}$ & b & SE & $\begin{array}{c}\text { Lower } \\
\mathbf{9 5 \%} \\
\text { C.L. for b } \\
\end{array}$ & $\begin{array}{c}\text { Upper } \\
\mathbf{9 5 \%} \\
\text { C.L. for b } \\
\end{array}$ & $R^{2}$ & P-value \\
\hline \multirow[t]{8}{*}{ Site 1} & Shell width (mm) & 807 & 0.014 & 0.036 & -0.057 & 0.085 & 0.263 & 0.002 & 0.259 & 0.268 & 0.939 & 0.000 \\
\hline & Shell height (mm) & 810 & 0.815 & 0.063 & 0.691 & 0.939 & 0.441 & 0.004 & 0.433 & 0.449 & 0.933 & 0.000 \\
\hline & Total weight (g) & 1039 & -3.910 & 0.027 & -3.962 & -3.858 & 2.882 & 0.023 & 2.838 & 2.927 & 0.940 & 0.000 \\
\hline & Wet weight (g) & 808 & -4.414 & 0.040 & -4.492 & -4.335 & 2.971 & 0.034 & 2.903 & 3.038 & 0.903 & 0.000 \\
\hline & Shell weight (g) & 805 & -4.049 & 0.027 & -4.102 & -3.996 & 2.812 & 0.023 & 2.767 & 2.858 & 0.949 & 0.000 \\
\hline & Gonad weight (g) & 369 & -6.459 & 0.191 & -6.835 & -6.083 & 3.929 & 0.163 & 3.609 & 4.250 & 0.613 & 0.000 \\
\hline & Intestine weight (g) & 380 & -5.012 & 0.101 & -5.211 & -4.813 & 2.841 & 0.086 & 2.671 & 3.011 & 0.741 & 0.000 \\
\hline & Dry weight (g) & 396 & -5.375 & 0.128 & -5.627 & -5.122 & 3.267 & 0.109 & 3.052 & 3.482 & 0.694 & 0.000 \\
\hline \multirow[t]{8}{*}{ Site 2} & Shell width (mm) & 889 & -0.126 & 0.034 & -0.193 & -0.058 & 0.273 & 0.002 & 0.268 & 0.277 & 0.943 & 0.000 \\
\hline & Shell height (mm) & 895 & 0.673 & 0.043 & 0.588 & 0.759 & 0.458 & 0.003 & 0.452 & 0.463 & 0.966 & 0.000 \\
\hline & Total weight (g) & 1101 & -3.953 & 0.017 & -3.986 & -3.920 & 2.929 & 0.015 & 2.901 & 2.958 & 0.974 & 0.000 \\
\hline & Wet weight (g) & 885 & -4.448 & 0.037 & -4.522 & -4.375 & 3.002 & 0.032 & 2.939 & 3.065 & 0.908 & 0.000 \\
\hline & Shell weight (g) & 885 & -4.135 & 0.022 & -4.179 & -4.091 & 2.897 & 0.019 & 2.859 & 2.934 & 0.963 & 0.000 \\
\hline & Gonad weight (g) & 407 & -6.248 & 0.171 & -6.584 & -5.911 & 3.773 & 0.146 & 3.487 & 4.059 & 0.624 & 0.000 \\
\hline & Intestine weight (g) & 402 & -4.925 & 0.097 & -5.115 & -4.734 & 2.758 & 0.082 & 2.596 & 2.920 & 0.737 & 0.000 \\
\hline & Dry weight (g) & 448 & -5.423 & 0.113 & -5.646 & -5.200 & 3.349 & 0.097 & 3.158 & 3.540 & 0.727 & 0.000 \\
\hline
\end{tabular}

Legend: No., number of specimen, a, intercept; SE, standard error; b, slop; C.L., confidence limits; $R^{2}$, correlation coefficient; P-value, level of significance.

Table 2: Values of regression equations describing the relative growth between shell length (mm) and each of shell measurements and weights of Donax trunculus at both studied sites.

\begin{tabular}{|c|c|c|c|c|c|c|c|c|c|c|c|c|}
\hline Site & $\begin{array}{l}\text { Measurements } \\
\text { and weights }\end{array}$ & No. & $\mathbf{a}$ & SE & $\begin{array}{c}\text { Lower } \\
95 \% \\
\text { C.L. for a } \\
\end{array}$ & $\begin{array}{c}\text { Upper } \\
95 \% \\
\text { C.L. for a } \\
\end{array}$ & b & SE & $\begin{array}{c}\text { Lower } \\
95 \% \\
\text { C.L. for b } \\
\end{array}$ & $\begin{array}{c}\text { Upper } \\
95 \% \\
\text { C.L. for b } \\
\end{array}$ & $R^{2}$ & P-value \\
\hline \multirow[t]{8}{*}{ Site 1} & Shell width (mm) & 113 & 0.213 & 0.172 & -0.127 & 0.554 & 0.298 & 0.009 & 0.281 & 0.315 & 0.917 & 0.000 \\
\hline & Shell height (mm) & 113 & 0.693 & 0.183 & 0.330 & 1.057 & 0.493 & 0.009 & 0.475 & 0.511 & 0.964 & 0.000 \\
\hline & Total weight (g) & 121 & -3.819 & 0.066 & -3.949 & -3.690 & 2.911 & 0.051 & 2.810 & 3.011 & 0.965 & 0.000 \\
\hline & Wet weight (g) & 112 & -4.559 & 0.164 & -4.884 & -4.234 & 3.061 & 0.127 & 2.810 & 3.312 & 0.842 & 0.000 \\
\hline & Shell weight (g) & 112 & -3.964 & 0.066 & -4.095 & -3.833 & 2.904 & 0.051 & 2.803 & 3.005 & 0.967 & 0.000 \\
\hline & Gonad weight (g) & 73 & -6.979 & 0.408 & -7.792 & -6.166 & 4.333 & 0.313 & 3.709 & 4.956 & 0.730 & 0.000 \\
\hline & Intestine weight (g) & 75 & -4.403 & 0.302 & -5.004 & -3.802 & 2.393 & 0.231 & 1.932 & 2.854 & 0.594 & 0.000 \\
\hline & Dry weight (g) & 33 & -5.843 & 0.593 & -7.053 & -4.633 & 3.530 & 0.464 & 2.583 & 4.477 & 0.651 & 0.000 \\
\hline \multirow[t]{8}{*}{ Site 2} & Shell width (mm) & 112 & -0.268 & 0.178 & -0.620 & 0.085 & 0.323 & 0.009 & 0.305 & 0.341 & 0.920 & 0.000 \\
\hline & Shell height (mm) & 111 & 0.985 & 0.178 & 0.633 & 1.338 & 0.481 & 0.009 & 0.463 & 0.499 & 0.963 & 0.000 \\
\hline & Total weight (g) & 118 & -3.830 & 0.061 & -3.950 & -3.709 & 2.932 & 0.048 & 2.838 & 3.026 & 0.970 & 0.000 \\
\hline & Wet weight (g) & 112 & -4.793 & 0.115 & -5.021 & -4.566 & 3.271 & 0.090 & 3.093 & 3.449 & 0.924 & 0.000 \\
\hline & Shell weight (g) & 112 & -3.813 & 0.067 & -3.946 & -3.681 & 2.798 & 0.052 & 2.695 & 2.902 & 0.963 & 0.000 \\
\hline & Gonad weight (g) & 82 & -7.552 & 0.396 & -8.339 & -6.764 & 4.799 & 0.307 & 4.189 & 5.410 & 0.754 & 0.000 \\
\hline & Intestine weight (g) & 82 & -4.574 & 0.288 & -5.147 & -4.001 & 2.541 & 0.223 & 2.097 & 2.985 & 0.619 & 0.000 \\
\hline & Dry weight (g) & 30 & -6.121 & 0.414 & -6.970 & -5.273 & 3.870 & 0.331 & 3.191 & 4.548 & 0.830 & 0.000 \\
\hline
\end{tabular}

Legend: No., number of specimen, a, intercept; SE, standard error; b, slop; C.L., confidence limits; $R^{2}$, correlation coefficient; P-value, level of significance.

\section{Length-height relationship \\ D. semistriatus}

The relationship between shell length and shell height $(\mathrm{L} / \mathrm{H})$ was linear and highly significant at both sites. It exhibited negative allometric growth, ranged from 0.154 to 0.536 at site 1 and from 0.409 to 0.495 at site 2 . The rate of growth in length exceeded that of height at both sites. 


\section{D. trunculus}

The monthly linear relation ships between shell length and shell height ranged from significant to highly significant at both sites. The slopes ranged between 0.365 to 0.538 at site 1 and between 0.428 to 0.626 at site 2 with negative allometric growth.

\section{Length-width relationship}

\section{D. semistriatus}

Length-width linear relationships (L/Wi) showed negative allometric growth ranged from 0.219 to 0.316 at site 1 and from 0.226 to 0.315 at site 2 . The positive intercept indicates that the rate of growth in length exceeded that of width at site 1 .

\section{D. trunculus}

Monthly linear relationships between shell length and shell width also exhibited negative allometric growth ranged from 0.164 to 0.365 at site 1 and 0.211 to 0.381 at site.

\section{Weight-length relationship}

Monthly logarithmic relationships between shell length (L) and each of body weights (total weight (TW), wet weight (WW), shell weight (SW), flesh dry weight (DW), intestine weight (IW) and gonad weight (GW)) of $D$. semistriatus and $D$. trunculus.

\section{D. semistriatus}

At site 1, D. semistriatus displayed negative allometric growth in TW/L, SW/L, IW/L and WW/L relationships with the exception of some months (July 2009 for TW/L; January 2009, January and February 2010 for IW/L; March, April, July 2009, January and April 2010 for WW/L). Positive allometric growth was observed for GW/L and DW/L relationships with the exception of some months (October 2009 and February 2010 for GW/L; December 2008, January, February, April, May, Jun, July, August, September and October 2009 for DW/L).

At site 2, D. semistriatus displayed negative allometric growth in TW/L, SW/L, IW/L and WW/L relationships with the exception of some months (August and September 2009 for TW/L; August 2009 for SW/L; November 2008, February, September October, February and May 2010 for WW/L; November 2008, February, March, 2009 and February 2010 for IW/L). On other hand Positive allometric growth was observed for GW/L and DW/L relationships with the exception of some months (July, May 2009 and February 2010 for GW/L; November, December 2008, January, February, March, April, May, Jun, July, August, September and November 2009 for DW/L).

\section{D. trunculus}

At site 1, TW/L, SW/L, IW/L and WW/L relationships displayed negative allometric growth with the exception of some months (November 2009, February and May 2010 for TW/L, SW/L; December 2008, January, March 2009 and April 2010 for IW/L; December 2008, January, March 2009 and March 2010 for WW/L). Positive allometric growth was observed for GW/L and DW/L relationships with the exception of some months (February 2009 and April 2010 for GW/L).

At site 2, D. trunculusus displayed negative allometric growth in TW/L, SW/L and IW/L relationships with the exception of some months (March, April, September 2009, February and April 2010 for SW/L; March, April, September, Octotober, November 2009, February and April 2010 for TW/L; December 2008, January, May, October, November 2009 and April 2010 for IW/L). Positive allometric growth achieved for WW/L, GW/L and DW/L relationships with the exception of some months (April, May, September 2009, December and April 2010 for WW/L; May 2009 for GW/L; January 2009 for DW/L). 


\section{Relative growth between populations \\ D. semistriatus}

The growth rate at site 2 was slightly higher than that at site 1 , however all regression relationships showed significant difference between the two sites $(\mathrm{P}=$ 0.0115 ,t test).

\section{D. trunculus}

As in D. semistriatus, the growth rate at site 2 was slightly higher than that at site 1, except SW/L. On other hand all regression relationships showed significant difference between the two sites $(\mathrm{P}=0.0192$, $\mathrm{t}$ test $)$.

\section{Indices}

\section{Gonad and digestive gland indices}

Female D. semistriatus

Monthly variations in the body component indices (digestive gland index DI and gonad index GI) at the studied sites are shown in Figs. (6 A\&B). Maximum values of GI are recorded in summer and spring months at both sites. These months were correlated with the time of sexual activity (see chapter II). On other hand, DI had more or less reversal relationship with GI.

\section{Male D. semistriatus}

Fig. (6 A) showed high relative gonad index of male D. semistriatus in July 2009 and March 2010 at site 1, while it was high from Jun to July 2009 at site 2. As mentioned above, these months coincided with sexual activity. Although DI had more or less reversal relationship with GI during most months, a slight synchronization seemed between them from December 2008 till April 2009 at site1 and from January 2009 till March 2009 at site 2 (Fig. 6 A\&B).

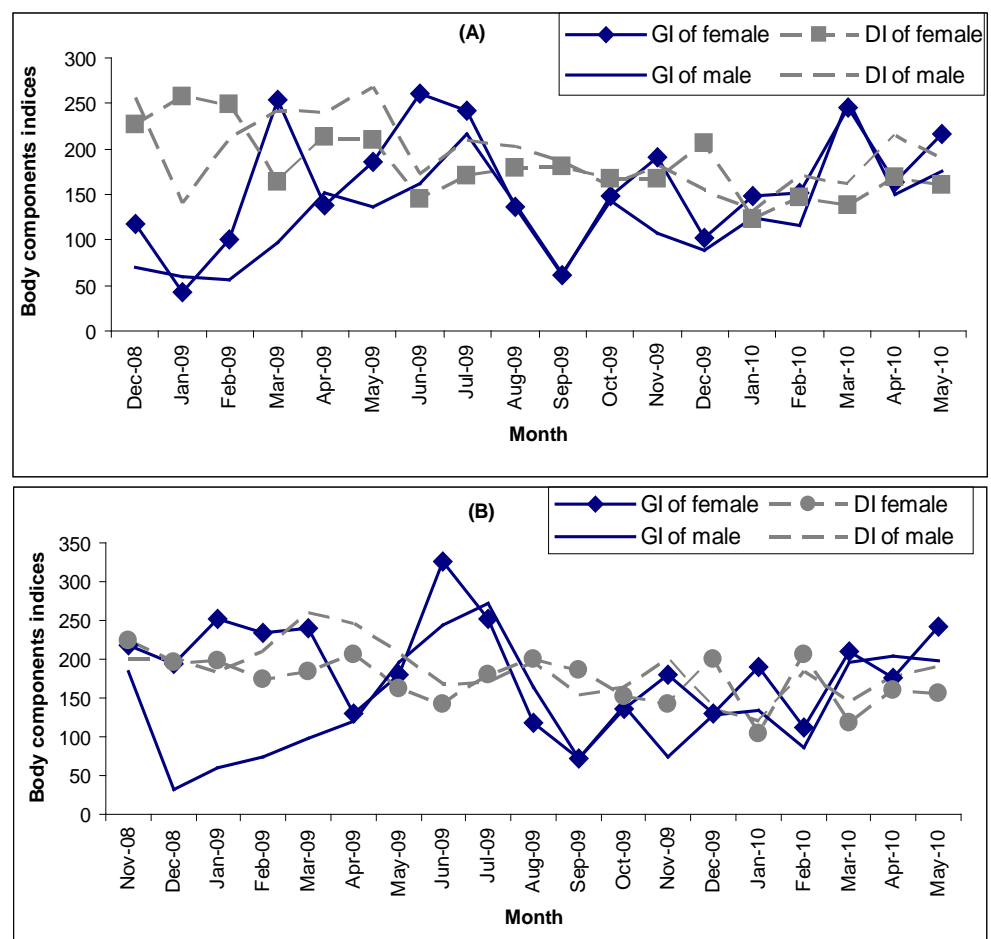

Fig. 6: Monthly variations in mean gonad index (GI) and digestive gland index (DI) of Donax semistriatus throughout the period of study at site 1 (A) and site 2 (B).

\section{Female D. trunculus}

Inspite of little number of $D$. trunculus, the present work showed that the highest values of GI appeared during the months of sexual activity such as March and April 2010 at site 1 and March 2010 at site 2. The apparent decline in GI was recorde in 
December 2009 at site 1. DI more or less inversely correlated with GI which showed a distinct rise in December 2009 (at site 1) and March 2009 at site 2 (Figs. 7 A\&C).

Male D. trunculus

At site1, male individuals also exhibited the highest values of GI during months of sexual activity (March \& Jun 2009 and March \& May 2010). A relative high value of GI was detected in November 2009 despite all individuals exhibited inactive stage (see chapter II). On other hand, the GI of male $D$. trunculus at site 2 performed lower value in November 2009, while the increase in GI (in Jun 2009 and May 2010) coincided mainly with the sexual activity.

DI, reflected reversal correlation with GI. However, a slight synchronization was detected from January to March 2009 (site 1) and from February to April 2009 (site 2). Also a distinct increment was observed in March 2009 at both sites (Fig. 7 $\mathrm{B} \& \mathrm{D})$.
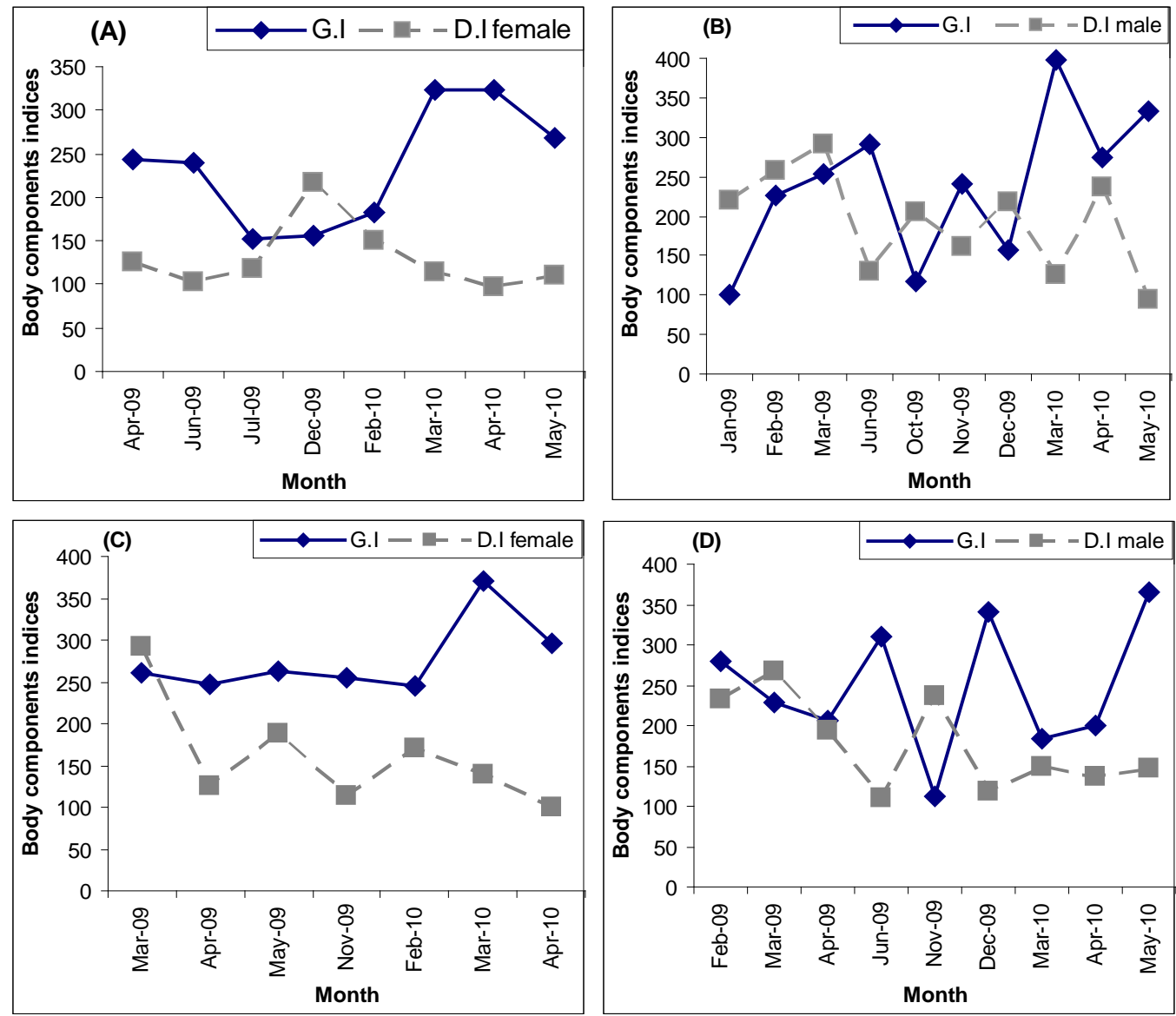

Fig. 7: Monthly variations in mean gonad index (GI) and digestive gland index (DI) of Donax trunculus throughout the period of study at site 1 (A \& B) and site 2 (C \& D).

\section{Condition index}

\section{Female D. semistriatus}

Fig. (8 A) showed monthly changes in condition index of female D. semistriatus at site 1 . Three peaks were observed; February, 2009, February and April 2010. More or less similar trend was recorded at site 2, the peaks was formed in February, Jun 2009 and February 2010 (Fig. 8 B). 


\section{Male D. semistriatus}

Monthly fluctuation in CI of male clams slightly differed from that of female. At site 1, the peaks were in January, April, July 2009, November, February and finally in April 2010. Sit 2 showed similar trend of seasonal variations (Fig. 8 A\&B).

Concerning variation in $\mathrm{CI}$ with the clam size at both sites, it is evident that the smallest and largest clams (4.1-8,16.1-20 and 20.1-24) had the greatest values at site 1 while it restricted to the largest groups at site 2 (Fig. $8 \mathrm{C}$ ).
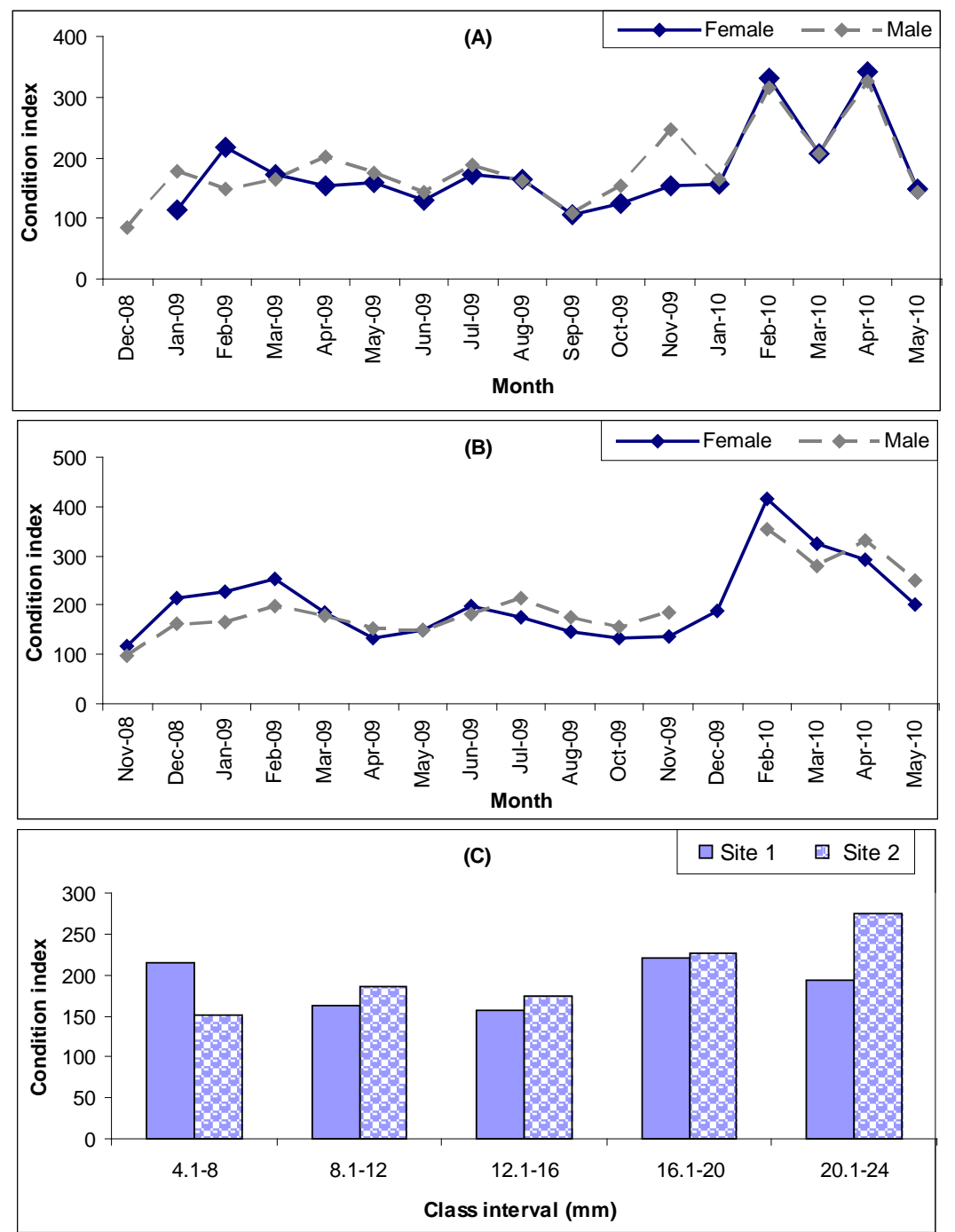

Fig. 8: Variation in condition index of both sexes of Donax semistriatus at site 1(A) and site 2 (B) and with size (C) during the studied period.

\section{D. trunculus}

Due to the scarce of this species in this site, the condition index was represented in few months. Two peaks appeared in each site in January 2009 and March 2010 at site 1 (Fig. 9 A). Also, increment in condition index recorded in January 2009 and December 2010 at site 2 (Fig. 9 B).

In both sites, CI directly correlated with size (Fig. 9 C).

\section{Bertalanffy growth parameters}

Estimation of asymptotic shell length (Lo) for females, males and the combined sexes at both sites was done. There was little variation between sexes or sites except that of females D. trunculus at both sites (Table 3). 

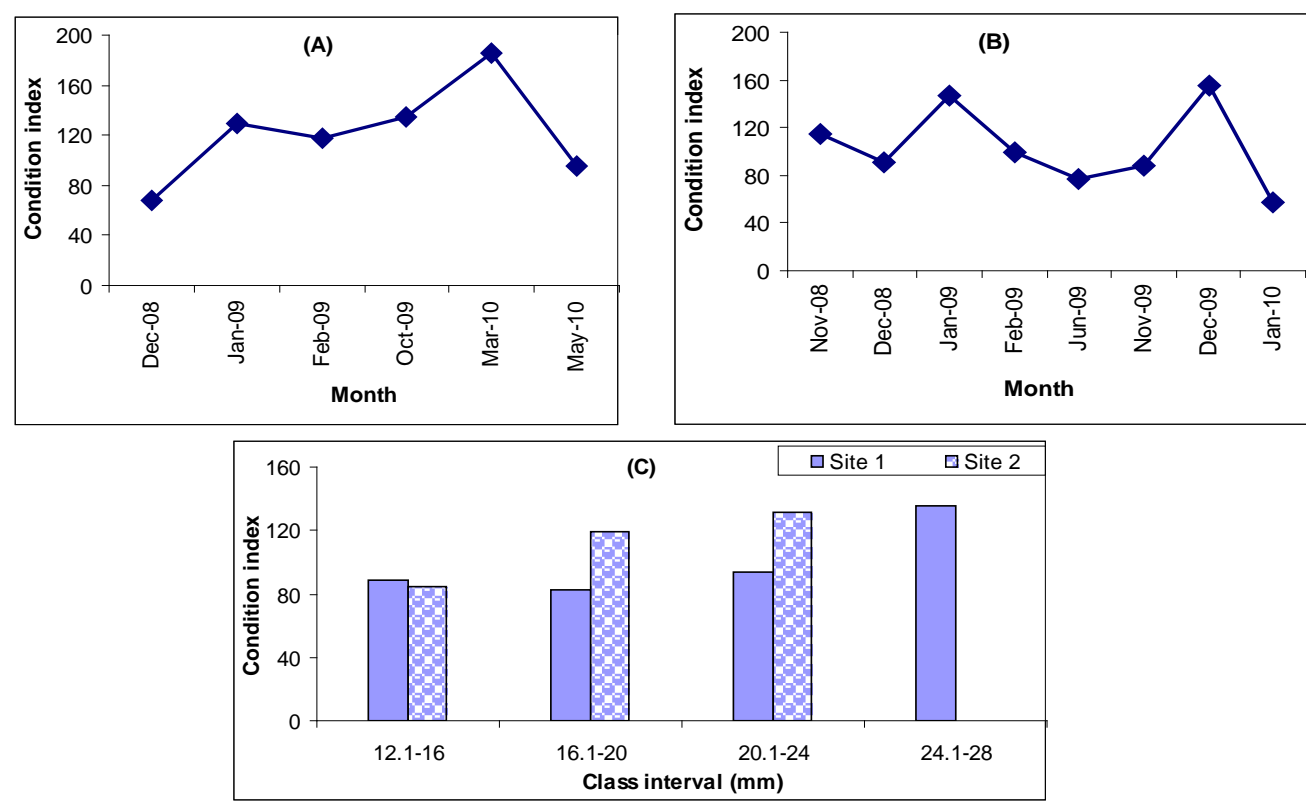

Fig. 9: Variation in condition index of both sexes of Donax trunculus at site 1(A) and site 2 (B) and with size (C) during the studied period.

Table 3: Von Bertalanffy growth parameters of the studied clams.

\begin{tabular}{cccccc} 
Species & Site & & Female & Male & Combined \\
\hline D. semistriatus & 1 & L $\infty$ & 23.1 & 25.2 & 25.2 \\
\hline & 2 & L $\infty$ & 24.15 & 24.15 & 24.15 \\
\hline D. trunculus & 1 & L $\infty$ & 32.55 & 30.45 & 32.55 \\
\hline & 2 & L $\infty$ & 27.3 & 29.4 & 32.55 \\
\hline
\end{tabular}

Legend: $\mathrm{L} \infty$, asymptotic length (mm)

\section{Age frequency}

Donax semistriatus

Both clam sexes exhibited three age groups (Table 4). Age group $<1$ only registered in the combined sexes in site 1 , the mean shell lengths were: $5.5,9.8,14.57$, and $20.31 \mathrm{~mm}$ for groups <1, I, II and III, respectively.

Table 4: Results of Bhattacharya's method for age groups determination of D. semistriatus at the studied sites.

\begin{tabular}{|c|c|c|c|c|c|c|c|}
\hline Species & Site & Sex & Group & Computed Mean & S.D. & Population & S.I. \\
\hline D. semistriatus & 1 & Female & 1 & 10.35 & 1.63 & 46 & n.a. \\
\hline & & & 2 & 14.78 & 1.82 & 229 & 2.57 \\
\hline & & & 3 & 19.99 & 1.71 & 44 & 2.95 \\
\hline & & Male & 1 & 10.18 & 1.35 & 56 & n.a. \\
\hline & & & 2 & 14.39 & 2.45 & 439 & 2.22 \\
\hline & & & 3 & 20.04 & 0.85 & 17 & 3.42 \\
\hline & & Total & $<1$ & 5.50 & 0.93 & 9 & n.a. \\
\hline & & & 1 & 9.81 & 1.23 & 100 & 3.99 \\
\hline & & 2 & 14.57 & 2.42 & 929 & 2.61 \\
\hline & & & 3 & 20.31 & 0.69 & 30 & 3.69 \\
\hline & & & 1 & 9.58 & 0.99 & 36 & n.a. \\
\hline & & & 2 & 14.69 & 2.80 & 302 & 2.70 \\
\hline & & Male & 1 & 20.58 & 1.11 & 14 & 3.01 \\
\hline & & & 2 & 14.79 & 0.95 & 70 & n.a. \\
\hline & & & 3 & 20.49 & 2.05 & 29 & 2.45 \\
\hline & & Total & 1 & 10.27 & 1.67 & 211.60 & n.a \\
\hline & & & 2 & 14.77 & 2.35 & 859 & 2.08 \\
\hline & & & 3 & 21.61 & 0.87 & 21.56 & 2.42 \\
\hline
\end{tabular}


On other hand, there were three groups only for the total individuals at site 2; $10.27 \mathrm{~mm}, 14.77 \mathrm{~mm}$ and $21.61 \mathrm{~mm}$, respectively. Generally, a new group appeared only in the combined sexes at site 1. reflecting probably the recruits of the population. The second age groups were the most common at both sites (Fig. 10).
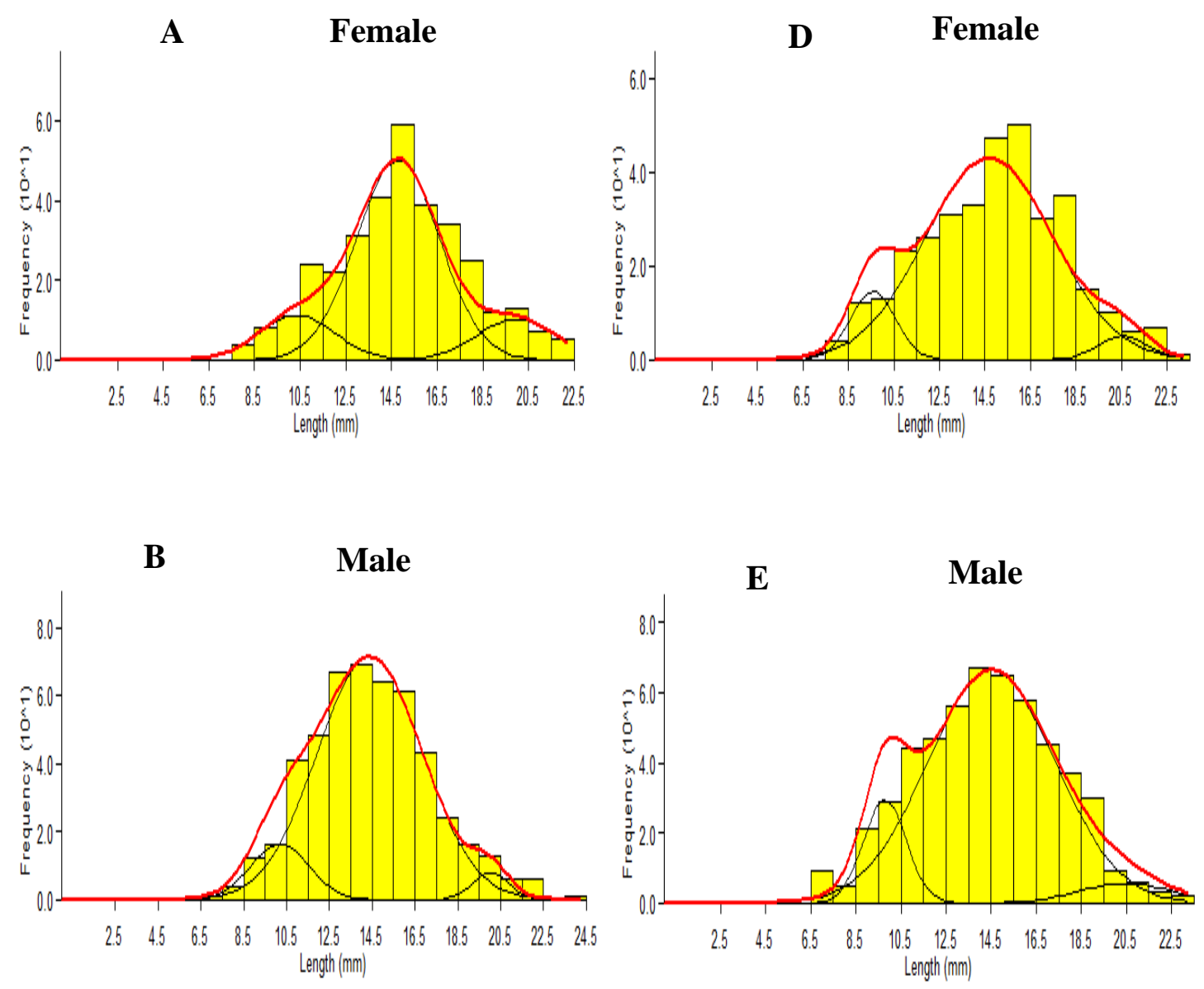

C Combined sexes

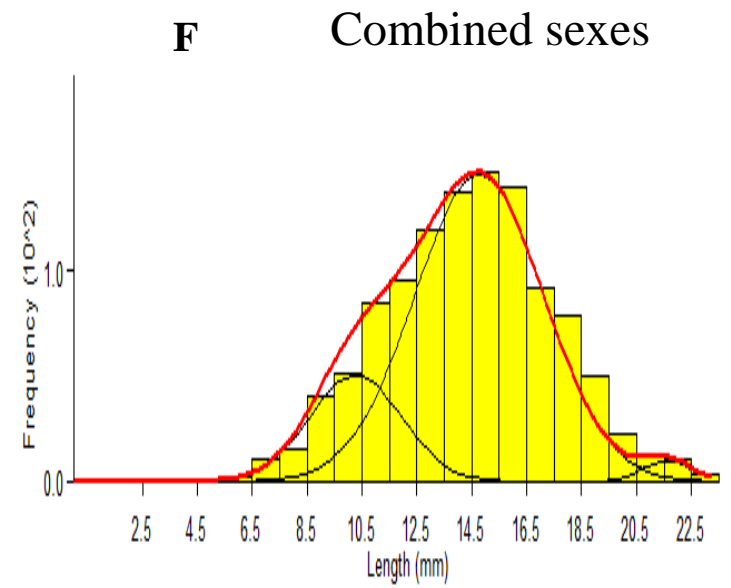

Fig.10: Bhattacharya's plots for age groups determination of D. semistriatus at site 1 (A, B \& C) and site 2 (D, E \& F). 


\section{Donax trunculus}

Female $D$. trunculus displayed only one group only $(21.5 \mathrm{~mm})$ while males showed three groups (18, 20.8 and $24.15 \mathrm{~mm}$ ) at site 1 (Table 5). The combined sexes of $D$. trunculus exihibited also three age groups (14.08, 18.65 and $22.39 \mathrm{~mm})$.

At site 2, female individuals also showed one age group $(21.67 \mathrm{~mm})$, while male individuals were too few to display any age group. Three age groups were recorded for the combined sexes at this site (Table 5 \& Fig. 11).

A

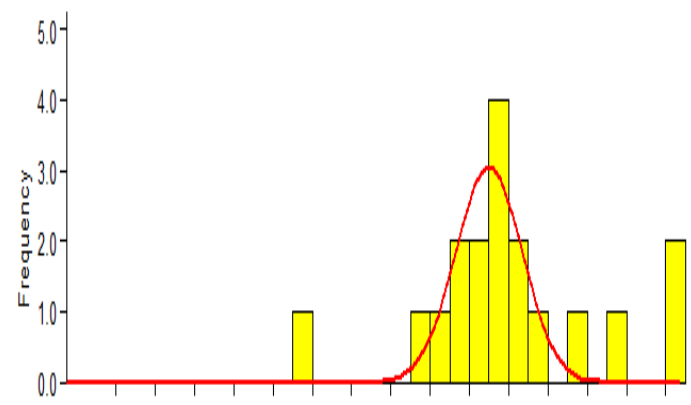

$2.54 .5 \quad 6.5 \quad 8.5 \quad 10.512 .514 .516 .518 .520 .522 .524 .526 .528 .530 .5$ Lenght $(\mathrm{mm})$

B

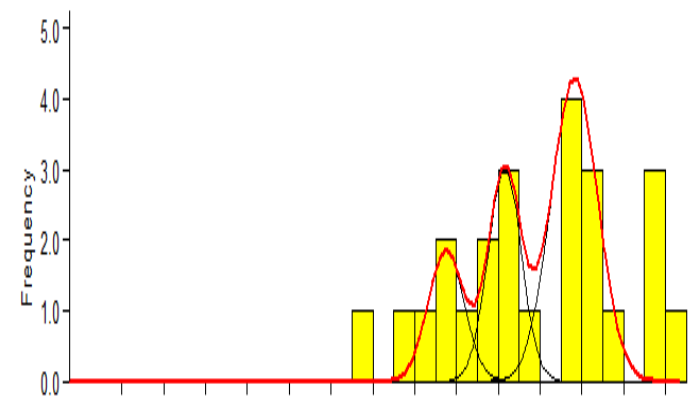

$2.5 \quad 4.5 \quad 6.5 \quad 8.5 \quad 10.5 \quad 12.5 \quad 14.5 \quad 16.518 .520 .522 .524 .526 .528 .5$ Lengh $(\mathrm{mm})$
C Combined sexes

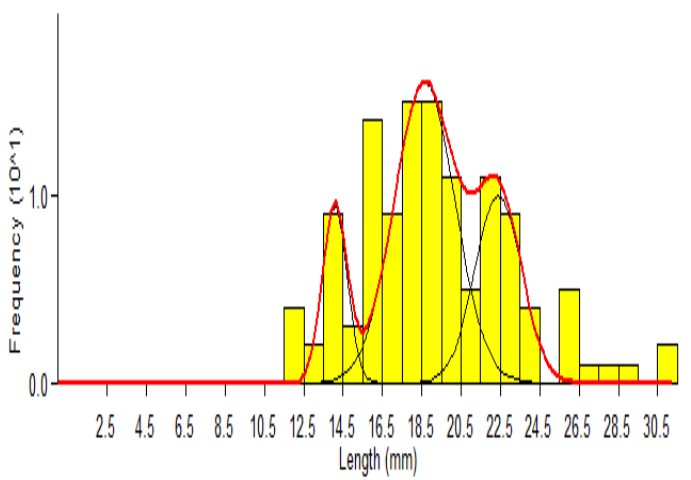

D

Female

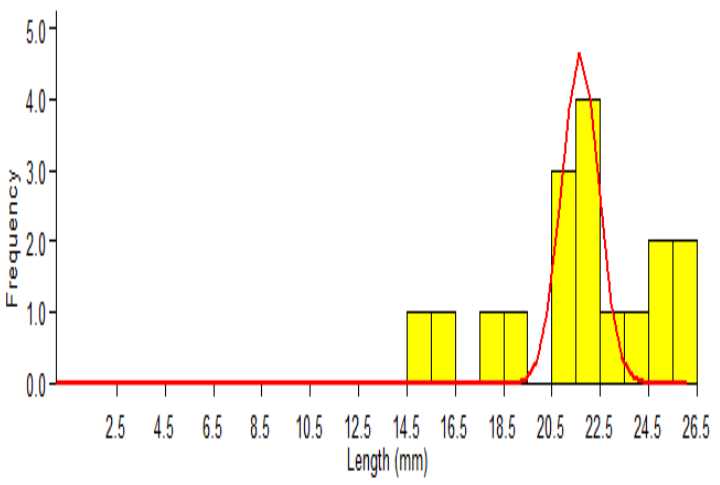

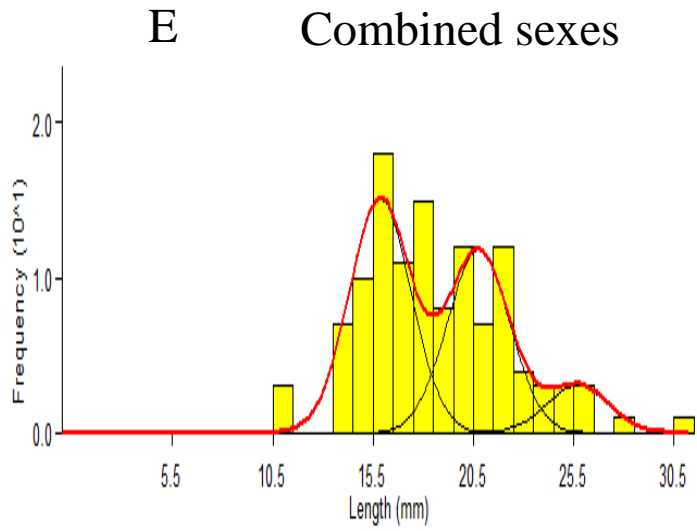

Fig.11: Bhattacharya's plots for age groups determination of D. trunculus at site 1 (A, B \& C) and site 2 (D \& E). 
Table 5: Results of Bhattacharya's method for age groups determination of $D$. trunculus at the studied sites.

\begin{tabular}{|c|c|c|c|c|c|c|c|}
\hline Species & Site & Sex & Group & $\begin{array}{c}\text { Computed } \\
\text { Mean }\end{array}$ & S.D. & Population & S.I. \\
\hline \multirow[t]{11}{*}{ D. trunculus } & 1 & Femle & 1 & 21.50 & 1.70 & 13 & n.a. \\
\hline & & Male & 1 & 18.00 & 0.85 & 4 & n.a. \\
\hline & & & 2 & 20.81 & 0.79 & 6 & 3.43 \\
\hline & & & 3 & 24.15 & 1.11 & 12 & 3.52 \\
\hline & & Total & 1 & 14.08 & 0.62 & 15 & n.a. \\
\hline & & & 2 & 18.65 & 1.54 & 62 & 4.23 \\
\hline & & & 3 & 22.39 & 1.19 & 30 & 2.74 \\
\hline & 2 & Female & 1 & 21.67 & 0.77 & 9 & n.a. \\
\hline & & Total & 1 & 15.85 & 1.53 & 58 & n.a. \\
\hline & & & 2 & 20.75 & 1.55 & 46 & 3.18 \\
\hline & & & 3 & 25.72 & 1.54 & 12 & 3.22 \\
\hline
\end{tabular}

\section{DISCUSSION}

Studying the population structure is the most effective way to recognize the ecological and biological behavior of bivalves. In the present work, population structure of $D$. semistriatus and $D$. trunculus from two sites at Edku shores was investigated.

The most dominate size of the carpet shell calm $D$. semistriatus was individuals within class intervals of 12.1-16 mm at both sites.

The most dominate size of $D$. trunculus was within class intervals of 18.1-22 $\mathrm{mm}$ and 14.1-18 $\mathrm{mm}$ at site 1 and site 2 respectively. The large and small clam individuals were found with low frequency at both sites. This result agrees with that of El-Ghalban (2010) for the same species. She stated that small and large clam individuals were found with low frequency and the class sizes of 10.1-20 mm were the dominant in Port Said. The scarcity of the clams may be correlated with food availability. Donn (1987) declared that more abundant food source may allow for increased survivorship and hence a larger population size. Defeo and de Alava (1995) also mentioned that differential mortality due to differences in salinity and food availability could affect the distributional pattern of $D$. hanleyanus population. The population of $D$. trunculus in the present study showed one period of recruitment each year. It was in November, December 2009 and January 2010 with the size of $12.4 \mathrm{~mm}$ for site 1 and in January 2009 with the size of 11.7 for site 2. However, Ramon et al. (1995) mentioned that the population of $D$. trunculus showed two periods of recruitment each year, one during July to September, with clams reaching a size of 9 to $11 \mathrm{~mm}$, and another between December and February, with a size range of $8.5-12$ $\mathrm{mm}$. Ramon (1993) added that the size at first maturation has been established at a size of around $12.5 \mathrm{~mm}$. This coincided with the results $(12.6 \mathrm{~mm})$ in site 1 , but lower than that in site 2 (15.4).

The little variability in population structure of $D$. trunculus in the present work probably due to the low numbers of this species in the collected samples. Manca Zeichen et al. (2002) mentioned that $D$. trunculus proved to be the dominant species of the macrofauna community in the South Adriatic Coast (Italy) between $0 \mathrm{~m}$ and 2 $\mathrm{m}$ depth, beyond that, the species disappears abruptly, giving way to the progressive dominance of $D$. semistriatus.

The present work revealed that, at site 1 small individuals of $D$. semistriatus found in July 2009. The first maturation appeared in individual with $8 \mathrm{~mm}$ shell 
length. At site 2, the smallest individuals were recorded in December 2008, first maturation recorded in individual with $7 \mathrm{~mm}$ shell length. Tirado and Salas (1999) failed to find a single juvenile of $D$. semistriatus while the juveniles of $D$. venustus $(0.5 \mathrm{~mm}$ to $9 \mathrm{~mm})$ found during the period of sexual activity (with less intense during most of the year) with a peak in September. Accordingly, we can conclude that the period number of recruitment in the carpet shell clams varies with longitude and also with species.

In the present study, the two species showed apparent general tendency toward negative allometry in most relationships between shell length and either of the other measurements or body weight parameters. These negative allometries and consequent narrow and elongated shape, may be an adaptive strategy to improve burrowing efficiency and depth within the substrate, avoiding dislodgement from the bottom sediments by local hydrodynamics. This assumption agreed with that of Gaspar et al. (2002) for D. semistriatus for L/H and L/Wi relationships respectively.

Growth and morphometric allometries could be correlated with environmental parameters and food availability.

The positive allometry exhibited in GW/L and DW/L of our study specially in the period of November 2009 to May 2010 (specially the observed increment of b value in April 2009 and April 2010). This may be due to gonadal development that took place during this period. Similarly, Fishelson, et al. (1996) declared a constant increase in the ratio of flesh per mm increase in length in $D$. trunculus and an increase in total weight per mm length also changed with growth.

Whilest Tirado and Salas (1999) recorded an important decrease in the ratio of flesh dry weight/length from June to August in $D$. semistriatus which related with peaks of spawning.

The positive allometry that appeared in most months between shell length and each of body weights, in the present investigation, may be related to many factors such as food availability, temperature and sexual maturity. Ramesh and Ravichandran (2008) found changes in the constant allometry of length-weight relationship of Turbo brunneus from Tuticorin (Southeast coast of India) are associated with an increase in size and sexual maturity.

Herrmann (2008) assumed that Sea surface temperature and food availability are key factors affecting growth of Mesodesma mactroides as well as aspects of population dynamics such as production, reproduction, recruitment and mortality. Urrutia et al., (1999) also mentioned that food availability and temperature constitutes a major determinant of growth in bivalves.

Differentiations of species morphometric relationships may be a consequence of distinct hydrological and sedimentological features between different geographical areas Gaspar et al., (2002). The present study showed slightly higher growth rate at site 2 than that of site 1 . Gonad index of both sexes of $D$. semistriatus recorded its maximum value during the time of sexual activity which detected in spring and summer seasons. This result was found in other bivalves such as Meretrix meretrix which its gonad index showed maximum value during February-August (Mane and RNagabhushanam, 1988). Gonad index of male C. glaucum also coincided with the reproductive condition (Mohammad, 2002). The fact of increment of gonad index during the time of reproductive activity was approached not only in bivalves but also in other invertebrates such as Paracentrotus lividus (Echinodermata: Echinoidea) in which gonad conditions being higher when gonad ascini were filled of both nutritive phagocytes and mature gametes (Fabbrocini and D’ Adamo, 2010). 
The gonad index of female and male $D$. trunculus increased during the months of sexual activity, however a higher value of GI seemed in November 2009 despite all individuals exhibited inactive stage. This observation is in agreement with that of Mohammad (2002) who reported that the gonad index of Papyridea papyracea not only decreased during some spawning seasons, but also increased during others. She concluded that the gonad index did not reflect accurately the gonad activity.

DI reflected reversal correlation with GI. However, a slight synchronization was detected. The obvious increment observed in spring may be related to the food availability. It can be concluded that gonad index as well as digestive gland index are somewhat inadequate as a measure of the reproductive activity and the digestive gland condition.

A parameter of economic relevance reflecting the ecophysiological conditions and the health of animals is the condition index. Seasonal changes in condition index of $D$. semistriatus at both sites reflected the reproductive activity in this species. The distinct decline in march 2010 in both sites may be due to the large percent of spent or partially spent individuals. A similar record was stated by Herrmann et al., (2010), who found that the annual reproductive cycle of $D$. hanleyanus correlated significantly with condition index which in turn correlated significantly with sea surface temperat. Also, the seasonal pattern of condition index in C. gallina clams was characterized by a peak value by the end of winter (February), just before spawning (Orban et al., 2006). As general, the maximum value of condition index at site 2 exceeded that of site 1.

Condition index of $D$. trunculus in the present study represented in few months due to fewer number of the collected samples. Two peaks appeared in each site (January 2009 and March 2010 at site 1 and January 2009 and December 2010 at site 2). In both sites, CI had greater values in the biggest size groups. Herrmann et al. (2009) mentioned that the condition index was not useful in describing the annual reproductive cycle of Mesodesma mactroides.

Generally, the condition index and gonad indices of $D$. semistriatus and $D$. trunculus were more or less synchronized at both sites.

Age determination in Donax may be relied on observation of the annual growth rings (Ansell and Lagardère, 1980) or the interpretation of length-frequency distributions (Ramón et al., 1995). Asymptotic shell length of D. semistriatus, in the present study, showed no or slight variation between sexes and sites. Generally it varied from $23.1 \mathrm{~mm}$ to $25.2 \mathrm{~mm}$. whereas a wider variation was observed in $₫$ between males at both sites. We can assume that asymptotic length varied with longitude and latitude for the same species. This is insured by Manca Zeichen et al. (2002) who mentioned that the growth parameters of $D$. trunculus from Italy were as follows: $\mathrm{I} \infty=47.56 \mathrm{~mm}$ and $\mathrm{K}=0 \cdot 30$. On other hand $D$. trunculus from Spain exhibited L $\infty$ of 46.0 (Ramon et al., 1995). Asymptotic length of the clam not only varied with longitude and latitude but also with species. Laudien (2002) recorded a von Bertalanffy growth function with an asymptotic length of $82 \mathrm{~mm}$. for Donax serra.

In the present work, we use Bhattacharya's method for age estimation because the annual growth ring of some Donax sp. in the Mediterranean (specially $D$. trunculus) did not form annual growth rings. Therefore, estimation of it's growth had relied entirely on the interpretation of length-frequency distributions (NeubergerCywiak et al., 1990). Laudien (2002) mentioned that growth mark analysis, both from surface rings and microgrowth internal lines are not suitable to estimate growth in $D$. $s p$. However, growth parameters could be estimated by fitting a common Von 
Bertalanffy growth parameter $(\mathrm{L},=82 \mathrm{~mm})$ to size-increment data pairs resulting from monthly length frequency distributional data.

Three age groups were identified for $D$. semistriatus at both sites. This result agreed with that of El-refaey (2006) who studied the age of $D$. semistriatus and found that it was ranged between one to three years (for individuals that are more than 11 $\mathrm{mm}$ ). Ansell et al. (1980) investigated another species of clams (D. vittatus) in the 2nd, 3rd, 4th and 5th yr, with shell lengths of 3 to $10 \mathrm{~mm}, 14$ to $22 \mathrm{~mm}, 22$ to $28 \mathrm{~mm}$ and 28 to $30 \mathrm{~mm}$, respectively.

$D$. trunculus exhibited three age groups in the present study. Male specimens were too few to exhibit any age group. On other hand, female $D$. trunculus displayed only one age group only. This may be due to the scarcity of the collected specimens in the present study. Ramón et al. (1995) concluded that ring formation in Donax trunculus did not occur in clams smaller than $15 \mathrm{~mm}$, whereas those larger than 25 $\mathrm{mm}$ all displayed a ring. There was a rapid increase in the shell length of $D$. trunculus during the first 2.5 months of the animal's life. By the end of this period, most of the animals attained 50\% of the maximal size (Neuberger-Cywiak, et al., 1990).

Our result agreed with that of El-refaey (2006) who declared that the age of $D$. trunculus ranged between one to four years (for individuals that are more than 14 $\mathrm{mm}$ ). It was of worth mentioned that the life span of bivalves differ from one region to another. The life span of $D$. trunculus in the South Adriatic Coast (Italy) was found to be of approximately 4 years. The population showed a maximum length of $37 \mathrm{~mm}$ and a longevity of 4 years (Manca Zeichen et al., 2002). Ansell et al. (1980) found that the life span of bivalves is shorter in Mediterranean than in Scottish waters, only D. vittatus in Scottish waters may live for 5 to7 yr. Also environmental factors (biotic and a biotic) may have observed effect on growth and production of the clam. ElGhobashy, et al. (2011) found that D. variabilis is susceptible to a biotic stressors which may affect it's production.

In conclusion, the study of population structure of $D$. semistriatus and $D$. trunculus showed that the most dominant size is the medium size. The population of D. semistriatus showed two periods of recruitments each year in July and December whilest that of $D$. trunculus recorded one period only extended from November to January, so the fishermen must avoid fishing during this months. Apparent general tendency toward negative allometry in the relationship between shell length and each of body parameters (except L/GW and L/DW) was observed. The growth rate at site 2 was slightly higher than that of site 1 for the two clams. For both species of Donax, the gonad indices were more or less coincided with the reproductive activity. $D$. semistriatus and $D$. trunculus recorded three age groups at both sites.

\section{REFERENCES}

Broom' M. J. (1982). Analysis of the Growth of Anadara granosa (Bivalvia: Arcidae) in Natural, Artificially Seeded and Experimental Populations: Mar. Ecol. Prog. Ser., 9: 69-79.

Defeo, O. and de Alava, A. (1995). Effects of human activities on long-term trends in sandy beach populations: the wedge clam Donax hanleyanus in Uruguay Mar Ecol. Prog. Ser., 123: 73-82.

El-Ghalban, E. M. A. (2010). Biological studies on commercial clams Donax trunculus in Port Said shores. M. Sc. thesis Marine Department, Faculty of Science, Suez Canal University. 
Fabbrocinia, A. and D'Adamo, R. (2010). Histological examination of the gonads of Paracentrotus lividus (Lamarck, 1816) from the Southern Adriatic coast. 41st S.I.B.M. CONGRESS Rapallo (GE), 7-11.

Fishelson, L.; Manelis, R.; Zuk-Rimon, Z.; Dotan, A.; Ornung, H. and Yawetz, A. (1996). Ecology, Enzymology and population dynamics of some selected littoral mollusks. UNEP/FAO: Final reports on research projects dealing with biological effects (Research Area III). MAP Technical Reports Series No. 103. UNEP, Athens.

Frihy O. E.; Iskander, M. M. and Badr, A. A. (2004). Effects of shoreline and bedrock irregularities on the morphodynamics of the Alexandria coast littoral cell, Egypt, Geo-Mar Lett, 24:195-211.

Gaspar, M. B.; Santos, M. N.; Vasconcelos, P. and Monteiro, C. C. (2002). Shell morphometric relationships of the most common bivalve species (Mollusca: Bivalvia) of the Algarve coast (southern Portugal). Hydrobiol., 477: 73-80.

Herrmann, M. (2008). Population dynamics of the Argentinean surf clams Donax hanleyanus and Mesodesma mactroides from open-Atlantic beaches off Argentina .Submitted for the degree Dr. rer. nat. of the Faculty 2 of Biology and Chemistry University of Bremen (Germany).

Herrmann, M.; Barreira, C.D.R.; Arntz, W. E.; Laudien, J. and Penchaszadeh, P. E. (2010). Testing the habitat harshness hypothesis: Reproductive biology of the wedge clam Donax hanleyanus (Bivalvia: Donacidae) at three Argentinean sandy beaches with contrasting morphodynamics. J. Mollusc Stud., 76: 33-47.

Herrmann, M.; Alfaya, J. E. F.; Lepore, M. L.; Penchaszadeh, P. E. and Laudien, J. (2009). Reproductive cycle and gonad development of the Northern Argentinean Mesodesma mactroides (Bivalvia: Mesodesmatidae). Helgol Mar Res 63:207218.

Laudien J. (2002). Population dynamics and ecology of the surf clam Donax serra (Bivalvia, Donacidae) inhabiting beaches of the Benguela upwelling system. Ber. Polarforsch. Meeresforsch. 432.

Laudien, J.; Brey, T. and Arntz, W. E. (2001). Reproduction and recruitment Pattern of the surf clam Donax serra (Bivalvia, Donacidae) from two Namibian sandy beaches. S. Af. J. mar. Sci., 23: 53-60.

Manatrinon, S.; Thonglor, O. U. and Boonyapakdee, A. (2011). Morphological Variation of Donax spp. from Five Beaches in Prachaupkhirikhan, Thailand. J. Agri. Sci. Technol., 1(A). 1109-1111.

Mane, U. H. and R-Nagabhushanam (1988). Reproduction in the edible bivalve shellfishes of Ratnagiri coast. CMFRI, bulletin 42, part one.

Mohammad, S. H. (2008). Vertical zonation and biometric parameter of the gastropod Cerithium scabridum in Suez Canal. Res. J. Environ. Sci., 2 (2):100-107.

Mohammad, S. H. (2002). Ecological and biological studies on the bivalves Cerastoderma glaucum and Papyridea papyracea, in lake Timsah "Suez Canal", Ph.D. thesis, Fac. Sci. Zool. Depart. Suez Canal Univ.

Neuberger-Cywiak, L.; Achituv, Y. and Mizrahi, L. (1990). The ecology of Donax trunculus Linneus and Donax semistriatus Poli from the Mediterranean coast of Israel. J. Exp. Mar. Biol. Ecol., 134:203-220.

Orban, E.; Di Lena, G.; Nevigato, T.; Casini, I.; Caproni, R.; Santaroni, G. and Giulini, G. (2006). Nutritional and commercial quality of the striped venus clam, Chamelea gallina, from the Adriatic sea. Food Chemistry, 101:1063-1070. 
Ramesh, R. and Ravichandran, S. (2008). A statistical approach on the length-weight relationship and allometry of Turbo brunneus. Rese. J. Environ. Sci., 2(2): 124-131.

Ramón, M. (1993). Estudio de las poblaciones de Chamelea gallina (Linnaeus, 1758) y Donax trunculus Linnaeus, 1758 (Mollusca:Bivalvia) en el Golfo de Valencia (Mediterráneo occidental). Ph. D. Thesis, University of Barcelona, Spain.

Ramón, M.; Abelló, P. and Richardson, C. A. (1995). Population structure and growth of Donax trunculus (Bivalvia: Donacidae) in the western Mediterranean. Marine Biology 121: 665-671.

Theodore E. Donn, Jr. (1987). Longshore distribution of Donax serra in two logspiral bays in the eastern Cape, South Africa. Mar. Ecol. Prog. Ser. 35: 217-222.

Urrutia, M.B.; Ibarrola, I.; Iglesias, J.I.P. and Navarro, E. (1999). Energetics of growth and reproduction in a high-tidal population of the clam Ruditapes decussatus from Urdaibai Estuary (Basque Country, N. Spain) J. Sea Res., 42: 35-48.

Zafar, F. H. Sh. and Ayub, Z. (2013). Allometric variations and condition factor in Cellana karachiensis (Winckqworth, 1930) found at two adjacent rocky coasts of Karachi, Pakistan. Ind. J. Geo-mari Sci., 42(6): 794-799. 

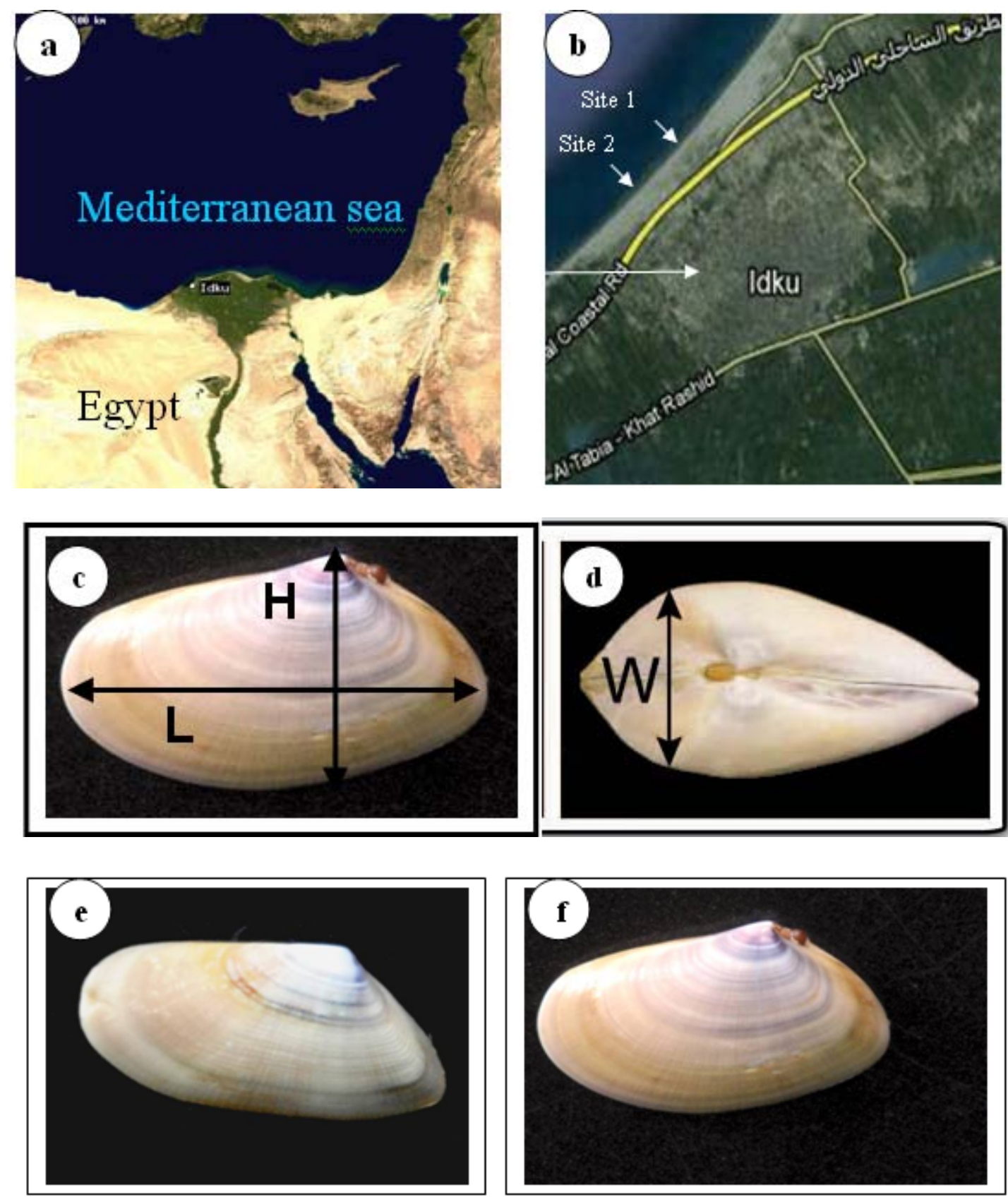

Plate 1: (a) \& (b) Location of Idku city (northern Egypt) and the sampling sites (map in satellite view copied from Google maps); (c) Distances measured to describe shell length (maximum anteriorposterior) and shell height (maximum ventro-dorsal) of Donax sp.; (d) Shell Width (maximum leftright); (e) Donax semistriatus; (f) Donax trunculus. 


\section{ARABIC SUMMARY}

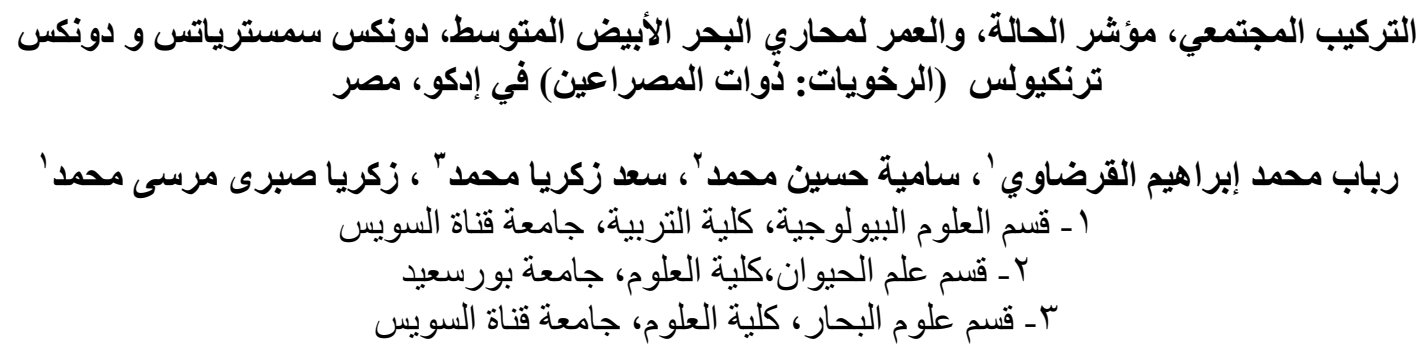

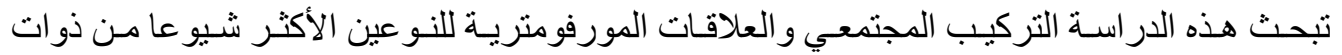

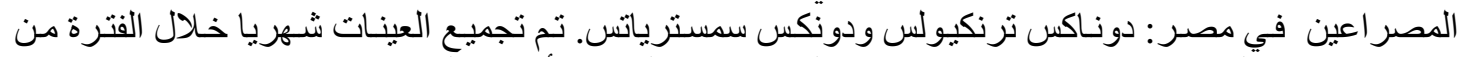

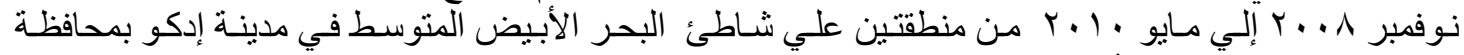

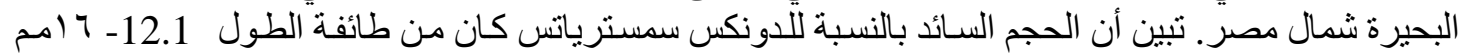

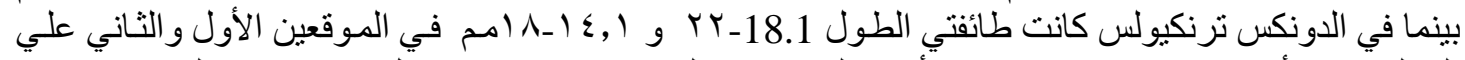

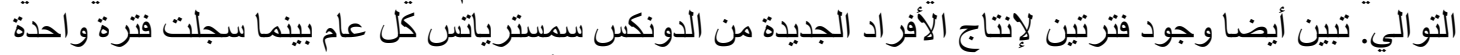

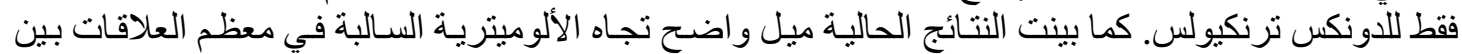

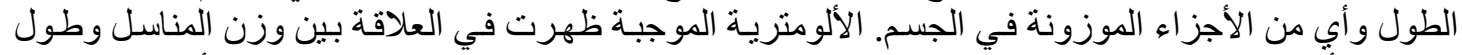

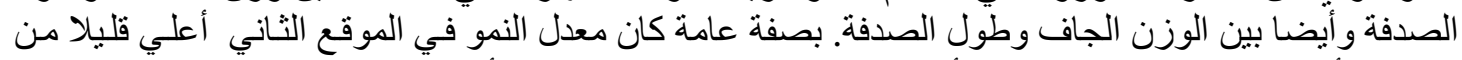

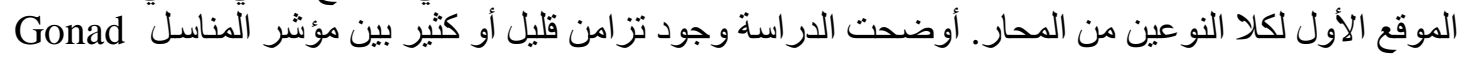

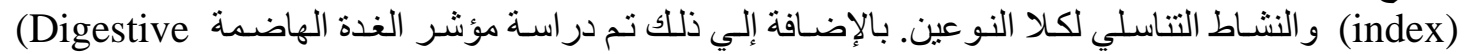
ومؤشر الحالة gland index) 